\title{
Adaptive Ant Colony Optimization on Mango Classification Using K-Nearest Neighbor and Support Vector Machine
}

\author{
Febri Liantoni ${ }^{1)}$, Luky Agus Hermanto ${ }^{2)}$ \\ ${ }^{1,2)}$ Teknik Informatika, Fakultas Teknologi Informasi, Institut Teknologi Adhi Tama Surabaya \\ Jl. Arief Rachman Hakim 100, Surabaya \\ Ifebri.liantoni@itats.ac.id \\ ${ }^{2}$ lukyagushermanto74@gmail.com
}

\begin{abstract}
Leaves recognition can use an image edge detection method. In this research, the classification of mango gadung and manalagi will be performed. In the preprocess stage edge detection method using adaptive ant colony optimization method. The use of adaptive ant colony optimization method aims to optimize the process of edge detection of a mango leaves the bone image. The application of ant colony optimization method on mango leaves classification has successfully optimized the result of edge detection of a mango leaves the bone structure. Results showed edge detection using adaptive ant colony optimization method better than Roberts and Sobel method. The result an experiment of mango leaves classification with k-nearest neighbor method get accuracy value equal to $66,25 \%$, whereas with the method of support vector machine obtained accuracy value equal to $68,75 \%$.
\end{abstract}

Keywords - Edge Detection, Ant Colony Optimization, Classification, K-Nearest Neighbor, Support Vector Machine

Article history:

Received 22 August 2017; Received in revised form 11 October 2017; Accepted 17 October 2017; Available online 28 October 2017

\section{INTRODUCTION}

Plants are the most important part of life on earth. Plants are used to provide oxygen for breathing, as food, fuel, medicine, cosmetics, and more. The plants also help in regulating the climate, providing habitats for animals, preventing a flood, as food for insects and other animals. One type of plant that is widely used is a fruit plant. This research was conducted to discuss the classification of mango species, especially gadung and manalagi mango. The process of mango classification is done by identifying based on the image of mango plant leaves. The leaves are one part of the plant that is often used to classify the types of plants (Jabal, Mohamad, Suhardi, Salehuddin, \& Illiasak, 2013). In this way, the leaf pattern recognition steps can be recognized by recognizing the structural characteristics of the leaves such as the shape and texture of the bone leaf structure. Each type of plant has different leaves that can be used as a reference to classify each type of plant (Fu \& Chi, 2006).

Edge detection is the process of finding information from the edge of the image that is the basic step in most image processing applications (Gonzales \& Wood, 1992). The edges of the image can be considered as the boundary between two different areas. Many approaches have been used to investigate the edges of images. Some commonly used edge detection methods are Roberts, Sobel, Prewitt and canny (Charu \&
Sunanda, 2013) (Om, Hanmandlu, Sultania, \& Dhruv, 2010). Ant colony optimization is an optimization method that can be used to detect image edges. This method is a method that mimics the heuristic behavior of ants to solve discrete optimization problems (Dorigo, Birattari, \& Stutzle, 2006). As Rahebi et al, research by combining optimization of ant colonies and genetic algorithms in improving ant dissemination to improve convergence (Rahebi, Elmi, \& Shayan, 2010).

In the previous research, adaptive ant colony optimization is done by dividing the image into 4 areas and ants are divided based on the gradient value of each region but the initial an ant dissemination is still done randomly, precision and recall of adaptive ant colony optimization reach $76.98 \%$ and $96.8 \%$ (Liantoni, Kartika, \& Tri, 2014). In 2015, research was conducted for ant colony optimization modification with initial an ant dissemination based on the gradient value of image pixels, this research obtained an average value of peak signal to noise ratio (PSNR) of 12.724 (Liantoni, 2015). While research on the classification of plant species has also been done. In 2017, the researchers themselves have done the grouping of herbal leaves using hierarchical clustering method based on the moment invariant feature, the use of hierarchical clustering method obtained clustering accuracy value of $87 \%$, whereas by using K-Means method obtained clustering accuracy of $81 \%$ (Liantoni \& Cahyani, 
2017). In 2015 researchers conducted research on the classification of herbal leaves Using Naïve Bayes Classifier method and K-Nearest Neighbor. This research compares the two methods to calculate the accuracy of both methods, the use of Naïve Bayes Classifier method obtained an accuracy of $75 \%$ while using the K-Nearest Neighbor method obtained an accuracy of $70.83 \%$. (Liantoni \& Nugroho 2015). In addition, researchers also conducted research on the classification of the leaves with the improvement of image features using the K-Nearest Neighbor, testing the result of leaves classification from the image which is on dataset has been built to get accuracy value about $86,67 \%$ (Liantoni, 2015). In 2015, Suastika et al classified mango plants based on leaf bone using Local Binary Pattern method (LBP), the highest accuracy is reached $78.5 \%$. (Riska, Cahyani, \& Rosadi, 2015).

In this research, edge detection process that generally uses conventional method will be changed using ant colony optimization method. The method proposed in the process of optimizing the deployment of ants. In general ant colony optimization method, the initial ant positions are randomly distributed, this triggers an imbalance in the distribution of ants in the pathfinding. Adaptive ant colony optimization method is proposed to optimize the result of edge detection of mango bone leaves structure so that it can be obtained a better classification of mango plant species. In this research K-Nearest Neighbor and Support Vector Machine method is used for the classification process.

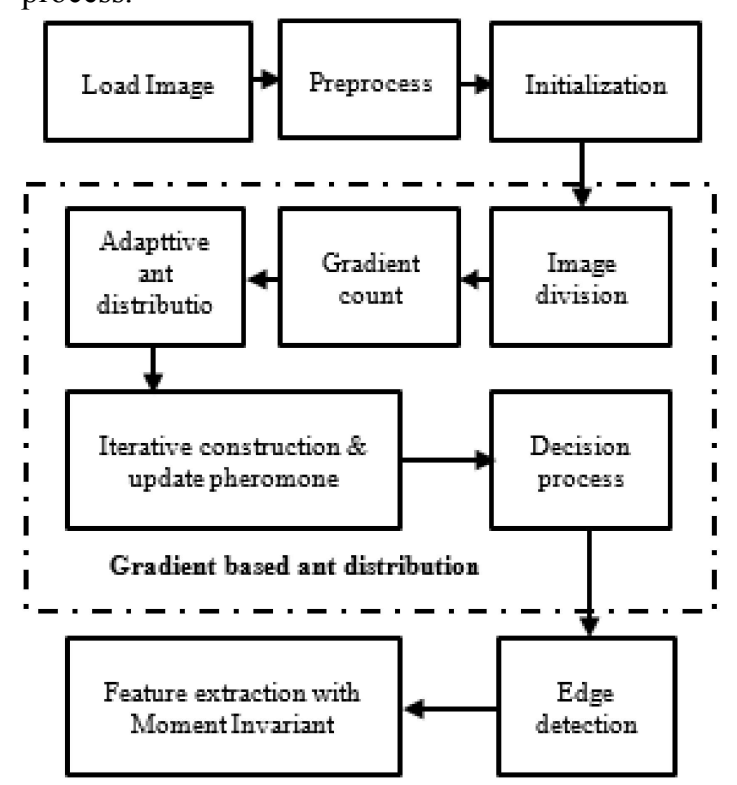

Figure. 1. Flow Mechanism of Adaptive ACO

\section{METHODOLOGY}

\section{A. Adaptive Ant Colony Optimization}

In this research, the detection process of mango leaf edge is done by using adaptive ant colony optimization method. This method refers to research that has been done earlier in 2015. The method is done by making changes to traditional ant colony optimization methods. The proposed method by dividing the image into 4 areas is equal then the ant will be spread by following the number of edge potentials of each area based on the value of the gradient. Because the edge is assumed to be at a high gradient value (Charu \& Sunanda, 2013). This method is expected to optimize the results of edge detection on mango leaf bone. Figure 1 is an adaptive ant colony optimization diagram.

In this research, instead of using Ant System, we prefer to use ACS algorithm. Since ACS has the pseudorandom proportional rule to optimize ant's movement. The pseudorandom proportional rule uses user-defined threshold ( $\left.\mathrm{q}_{0}\right)$, that value is between 0 to 1 , to complement traditional random proportional rule. On each ant's movement, it is needed to randomly generate $\mathrm{q}$ which value is distributed between 0 and 1 . If $q$ is greater, then the random proportional rule is used to decide ant's movement. However, if $\mathrm{q}<\mathrm{q}_{0}$, an ant should move according to transition that maximizes $\tau_{i, j}^{\alpha} \tau_{i, j}^{\beta}$. The random proportional rule is given in equation(1).

$$
P_{i, j}^{(n)}=\frac{\left.\left(\tau_{i, j}^{n-1}\right)^{\alpha}\left(\eta_{i, j}\right)^{\beta}\right)}{\left.\sum_{j \in \Omega_{i}}\left(\tau_{i, j}^{n-1}\right)^{\alpha}\left(\eta_{i, j}\right)^{\beta}\right)} \text { if } j \in \Omega_{i}
$$

The probability of ant movement to a pixel on row $\mathrm{i}$ and column $\mathrm{j}(P i j)$ equals to a multiplication of pheromone $(\tau)$ and heuristic information $(\eta)$ which is divided by total multiplication of its 8 connectivity neighborhood. Both pheromone and heuristic information is equipped with pheromone weighting factor $(\alpha)$ and heuristic information weighting factor $(\beta)$. In addition, ACS has two pheromone update mechanisms, which are local pheromone update and global pheromone update. Local pheromone update is firstly introduced in ACS and considered as the most interesting contribution of ACS (Jiang, Weiyu, \& Shengli, 2008). Formulas for local pheromone and global pheromone updates are defined in equation (2) and equation (3).

$\tau_{i, j}=(1-\varphi) \tau_{i, j}+\varphi \tau_{0}$

$\tau_{i, j}=(1-\rho) \tau_{i, j}+\rho \Delta \tau_{i, j}$

Local pheromone update aims to diversify the search performed by subsequent ants during an iteration (Dorigo et al. 2006). It is implemented by using pheromone decay $(\varphi)$ and pheromone init $\left(\tau_{0}\right)$ to decrease the pheromone concentration on the traversed edges. Therefore subsequent ants can produce different solutions. Whereas pheromone evaporation rate $(\rho)$ and total deposit pheromone 
$\left(\Delta \tau_{i, j}\right)$ are used to implement global pheromone update.

\section{B. Classifier}

The last stages of this research are the process of classification of herbal leaf image pattern. The K-Nearest Neighbor method and the Support Vector Machine are used for the classification process. $\mathrm{KNN}$ algorithm determines the distance value in testing data testing with training data based on the smallest value of the nearest neighboring value (Goujon, Chaoqun, \& Jianhong, 2007). According to Prasetyo, SVM method (Support Vector Machine) is a theory of statistical learning and can give better results than other methods SVM can work well on data with a highdimensional (Prasetyo \& Eko, 2012). The results of both methods will be compared to determine the best accuracy of the method used. The steps taken in the leaves classification process are shown in Figure 2.

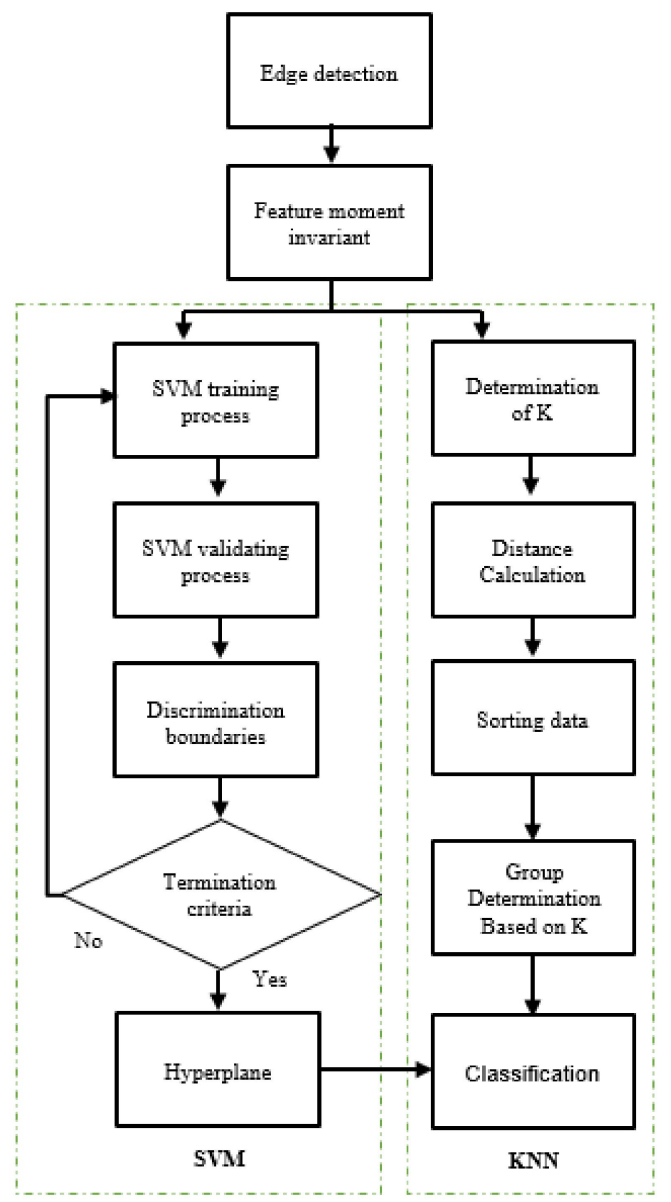

Figure. 2. The leaves classification process

\section{RESULT}

Tests conducted have a purpose to determine the level of system success in the classification of mango leaves. Scenario testing is done with the amount of mango leaves image data of 400 photos, consisting of 200 leaves of gadung mango and 200 manalagi mangoes. The testing process is done by dividing the dataset into two parts ie $80 \%$ or 320 images used as training data and $20 \%$ or 80 images as test data. The tests were performed at the edge detection stage using the ACO adaptive method which would be compared with edge detection using conventional methods. Testing the classification of mango plants based on leaf structure. Illustration of leaf images for gadung and manalagi as shown in Figure 3.

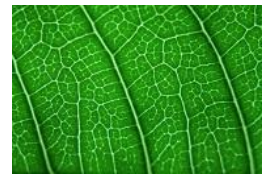

a

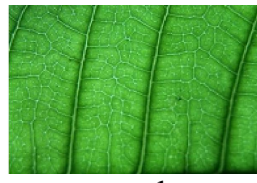

b
Figure. 3. Image a) Gadung b) Manalagi

Leaves of mango gadung have a thicker bone structure than mango manalagi.

\section{A. Preprocessing Result}

Preprocess in this research aims to convert RGB image into a gray image. Pre-processed results on the mango leaf image as shown in Figure 4.

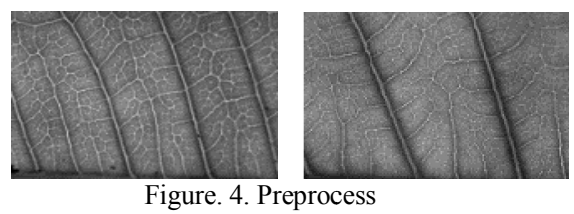

\section{B. Adaptive Ant Colony Optimization Result}

In this research, the adaptive ant colony optimization method was used as a substitute for conventional edge detection method. adaptive ant colony optimization used in accordance with research that has been done (Liantoni, Kartika, \& Tri, 2014). The reason for doing the comparison to find out what edge detection results are better than Roberts and Sobel. An example of ant colony optimization edge detection results compared to the method of edge detection of a Sobel and Roberts as shown in Figure 5.

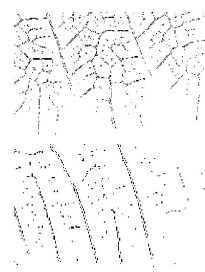

a

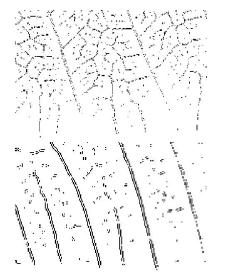

b

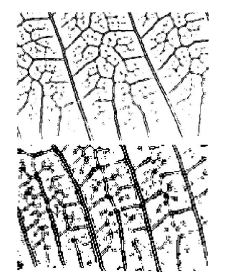

$\mathrm{c}$
Figure. 5. Result in a) Roberts b) Sobel c) Adaptive ACO

After the process of edge detection of mango leaf bone structure then performed feature extraction of the image. At this stage, it will perform the process of mango leaves feature 
TABEL 1. Classification Result

\begin{tabular}{|c|c|c|c|c|c|}
\hline \multirow{2}{*}{ Data } & \multicolumn{3}{|c|}{ Class } & \multicolumn{2}{|c|}{ Result } \\
\hline & Ground truth & $K N N$ & $S V M$ & $K N N$ & $S V M$ \\
\hline 1 & Gadung & Gadung & Gadung & True & True \\
\hline 2 & Gadung & Gadung & Manalagi & True & False \\
\hline 3 & Gadung & Manalagi & Manalagi & False & False \\
\hline 4 & Gadung & Gadung & Gadung & True & True \\
\hline 5 & Gadung & Gadung & Gadung & True & True \\
\hline 6 & Manalagi & Gadung & Manalagi & False & True \\
\hline 7 & Manalagi & Manalagi & Manalagi & True & True \\
\hline 8 & Manalagi & Gadung & Manalagi & False & True \\
\hline 9 & Manalagi & Manalagi & Gadung & True & False \\
\hline
\end{tabular}

extraction using a seven-moment invariant method. Features of the leaf bone that will be used as the basis of differentiation of mango leaves of Gadung mango and Manalagi mango. Phase extraction feature of mango leaf bone is done to obtain feature seven invariant moment value. The extraction feature data will then be processed to normalize the value at intervals between 0 and 1 . The value 0 for the lowest value and 1 for the highest value. Normalization feature values will then be used as mango leaf classification data using support vector machine and k-nearest neighbor method.

\section{Classification Result}

The classification testing process is conducted on 80 test data images. The classification of test data images will be matched with the training data totaling 320 images. Examples for some mango classification results such as from data testing are shown in Table 1.

Table 1 shows the true results representing the corresponding values based on the actual class and also corresponding to the system whereas the false value represents the improper between actual classes and classes in the system. By using knearest neighbor method obtained 53 leaf images classified correctly according to the actual class. From the results of this test, it is obtained system accuracy of $53 / 80=66.25 \%$. While using support vector machine method obtained 56 leaf pictures are classified correctly according to the actual class. Then obtained the system accuracy of 55/80 $=68.75 \%$.

\section{CONCLUSION}

The conclusion obtained from this research is an application of ant colony optimization method for edge detection successfully optimize the result of edge detection of a mango leaves the bone structure. This is demonstrated by the results of bone structure detection with ant colony optimization method that is thicker and more detailed than using Roberts and Sobel edge detection. The results of the classification process testing with k-nearest neighbor method obtained an accuracy of $66.25 \%$, whereas with the support vector machine method obtained an accuracy of $68.75 \%$.

\section{ACKNOWLEDGEMENT}

The author would like to thank the Direktorat Jenderal Penguatan Riset dan Pengembangan (Kemenristekdikti) who has provided financial support for this research.

\section{REFERENCES}

Charu, \& Sunanda. (2013). Edge Detection of an Image Based on Ant Colony Optimization Technique. International Journal of Science and Research, 2(6), 114-120.

Dorigo, Birattari, \& Stutzle. (2006). Ant Colony Optimization: Artificial Ants as a Computational Intelligence Technique. IEEE Computational Intelligence Magazine.

Fu, \& Chi. (2006). Combined thresholding and neural network approach for vein pattern extraction from leaf images. Image Signal Process, 153(6).

Gonzales, \& Wood. (1992). Digital Image Processing. Addison Wesley.

Goujon, Chaoqun, \& Jianhong. (2007). Data Clusterin Theory, Algorithms, and Applications. Virginia: SIAM.

Jabal, Mohamad, Suhardi, Salehuddin, \& Illiasak. (2013). Leaf Features Extraction and Recognition Approaches to Classify Plant. Journal of Computer Science, 9, 1295-1304.

Jiang, Weiyu, \& Shengli. (2008). An Ant Colony Optimization Algorithm For Image Edge Detection. IEEE Congress on Evolutionary Computation, (pp. 751-56).

Liantoni. (2015). Klasifikasi Daun Dengan Perbaikan Fitur Citra Menggunakan Metode K-Nearnest Neighbor. ULTIMATICS, Jurnal Teknik Informatika, 7(2), 98-104. 
Liantoni, \& Cahyani. (2017). Pemanfaatan Hierarchical Clustering Untuk Pengelompokkan Daun Berdasarkan Fitur Moment Invariant. Jurnal Ilmiah Edutic, 3(2), 91-98.

Liantoni, \& Nugroho. (2015). Klasifikasi Daun Herbal Mengggunakan Metode Naïve Bayes Classifier dan K-Nearest Neighbor. Jurnal Simantec, 5(1), 9-16.

Liantoni, Kartika, \& Tri. (2014). Adaptive Ant Colony Optimization based Gradient for Edge Detection. Journal of Computer Science, 7(2), 78-84.

Liantoni, Suciati, \& Fathicha. (2015). Modifikasi Ant Colony Optimization Berdasarkan Gradient Untuk Deteksi Tepi Citra. Jurnal Buana Informatika, 6(3), 43-52.

Om, P., Hanmandlu, Sultania, \& Dhruv. (2010). A Novel Fuzzy Ant System For Edge Detection. IEEE/ACIS International Conference on Computer and Information Science, (pp. 22833).
Prasetyo, \& Eko. (2012). Data Mining: Konsep Dan Aplikasi Menggunakan MATLAB. Yogyakarta: Andi Offset.

Rahebi, Elmi, \& Shayan. (2010). Digital image edge detection using an ant colony optimization based on genetic algorithm. IEEE Conference In Cybernetics and Intelligent Systems (CIS), (pp. 145-49).

Riska, S., Cahyani, L., \& Rosadi, M. (2015). Klasifikasi Jenis Tanaman Mangga Gadung dan Mangga Madu Berdasarkan Tulang Daun. Jurnal Buana Informatika, 6(1), 41-50. 